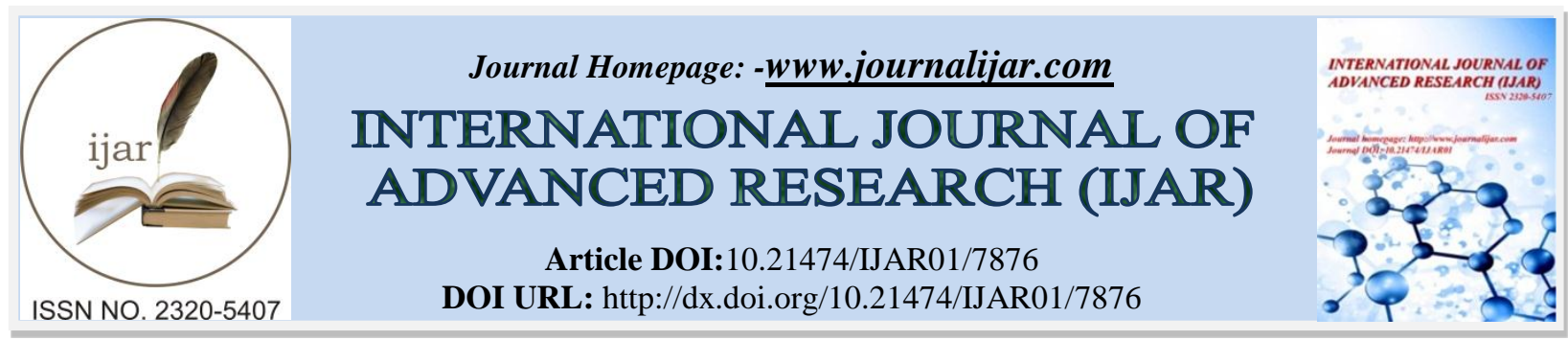

RESEARCH ARTICLE

\title{
RADIOLOGICAL HAZARD ASSESSMENT FOR FLY ASH AND ENVIRONMENTAL MATERIALS FROM MORUPULE A COAL-FIRED POWER STATION IN BOTSWANA.
}

John Mudiwa ${ }^{1}$, E. O. Darko ${ }^{1,2}$ and A. Faanu ${ }^{1}$.

1. School of Nuclear and Allied Sciences, University of Ghana, Legon-Accra, Ghana.

2. Radiation Protection Institute, Ghana Atomic Energy Commission, Accra, Ghana.

\section{Manuscript Info}

Manuscript History

Received: 10 August 2018

Final Accepted: 12 September 2018

Published: October 2018

Keywords:-

Gamma ray, spectrometry, radiological impact, radium equivalent activity.

\section{Abstract}

This study was undertaken to determine the occupational and public radiation hazards due to the usage of fly ash and other environmental materials from Morupule A Coal-Fired Power Station and its environs for construction purposes. Identification and quantification of the natural radionuclides K-40, Th-232 and U-238 in water (from the ash ponds), soil, coal and fly ash samples was done through direct gamma ray spectrometry. The average radium equivalent activity $\left(\mathrm{Ra}_{e q}\right)$, representative level index $\left(\mathrm{I}_{\gamma r}\right)$, internal hazard index $\left(\mathrm{H}_{\text {int }}\right)$ and external hazard index $\left(\mathrm{H}_{\text {ext }}\right)$ values for fly ash samples were 149.038 $\mathrm{Bq} / \mathrm{kg}, 1.031 \mathrm{~Bq} / \mathrm{kg}, 0.536 \mathrm{~Bq} / \mathrm{kg}$ and $0.403 \mathrm{~Bq} / \mathrm{kg}$ respectively. For coal samples, the average $\mathrm{Ra}_{e q}, \mathrm{I}_{\gamma r}, \mathrm{H}_{\text {int }}$ and $\mathrm{H}_{\text {ext }}$ values were 58.662 $\mathrm{Bq} / \mathrm{kg}, 0.407,0.207$ and 0.158 respectively. The average $\mathrm{Ra}_{e q}, \mathrm{I}_{\gamma r}$, $\mathrm{H}_{\text {int }}$ and $\mathrm{H}_{\text {ext }}$ values for soil samples were $30.296 \mathrm{~Bq} / \mathrm{kg}, 0.225,0.100$ and 0.082 respectively. Those for water samples were $1.516 \mathrm{~Bq} / \mathrm{kg}$, $0.011,0.005$ and 0.004 respectively. The radium equivalent activity, representative level index, external and internal hazard indices for all samples were all within the recommended international values for their safe use as construction material. Results from this study show that all study samples pose no significant radiological impact to both the workers and public members within Morupule A Coal-Fired Power Station and its surroundings.

Copy Right, IJAR, 2018,. All rights reserved.

\section{Introduction:-}

Human activities like the coal combustion for electricity generation in coal-fired power stations are some of the potential sources of public and occupational exposure to natural radioactivity. In coal-fired power stations, coal combustion takes place and gaseous products are emitted into the atmosphere through the stack gas pipe. This coal contains some trace quantities of long-lived radionuclides that give rise to natural radioactivity such as Th-232, U238, Ra-226, as well as K-40. During coal combustion, most non-combustible materials, including most of these radionuclides, remain in the fly-ash formed. In spite of this, coal-fired power stations and other types of power stations that use fossil fuels are presently not under any regulation for natural radioactivity releases in Botswana. A radiological harzard assessment of these fossil-fired power stations has never been performed in Botswana. This is of great concern since most electricity in Botswana is generated by coal-fired power stations. Morupule A CoalFired Power Station has a combined power output of 132 MW and has been in operation since 1986. 


\section{Description of study area}

Morupule A Coal-Fired Power Station is the study area, located in Morupule (Botswana) at GPS coordinates $22.520^{\circ} \mathrm{S} 27.037^{\circ} \mathrm{E}$. Its surroundings, within a distance of $6 \mathrm{~km}$, are also part of the study area. A distinct part of the study area is Kgaswe Primary School, which is located approximately $800 \mathrm{~m}$ to the south at coordinates of $22.530^{\circ} \mathrm{S} 27.038^{\circ} \mathrm{E}$. The nearest village is Palapye, located approximately $6 \mathrm{~km}$ to the east. The land surrounding the power station is mostly utilized as a communal grazing area for livestock such as goats, sheep and cattle. Figure 1 shows all the relevant sampling points from the study area.

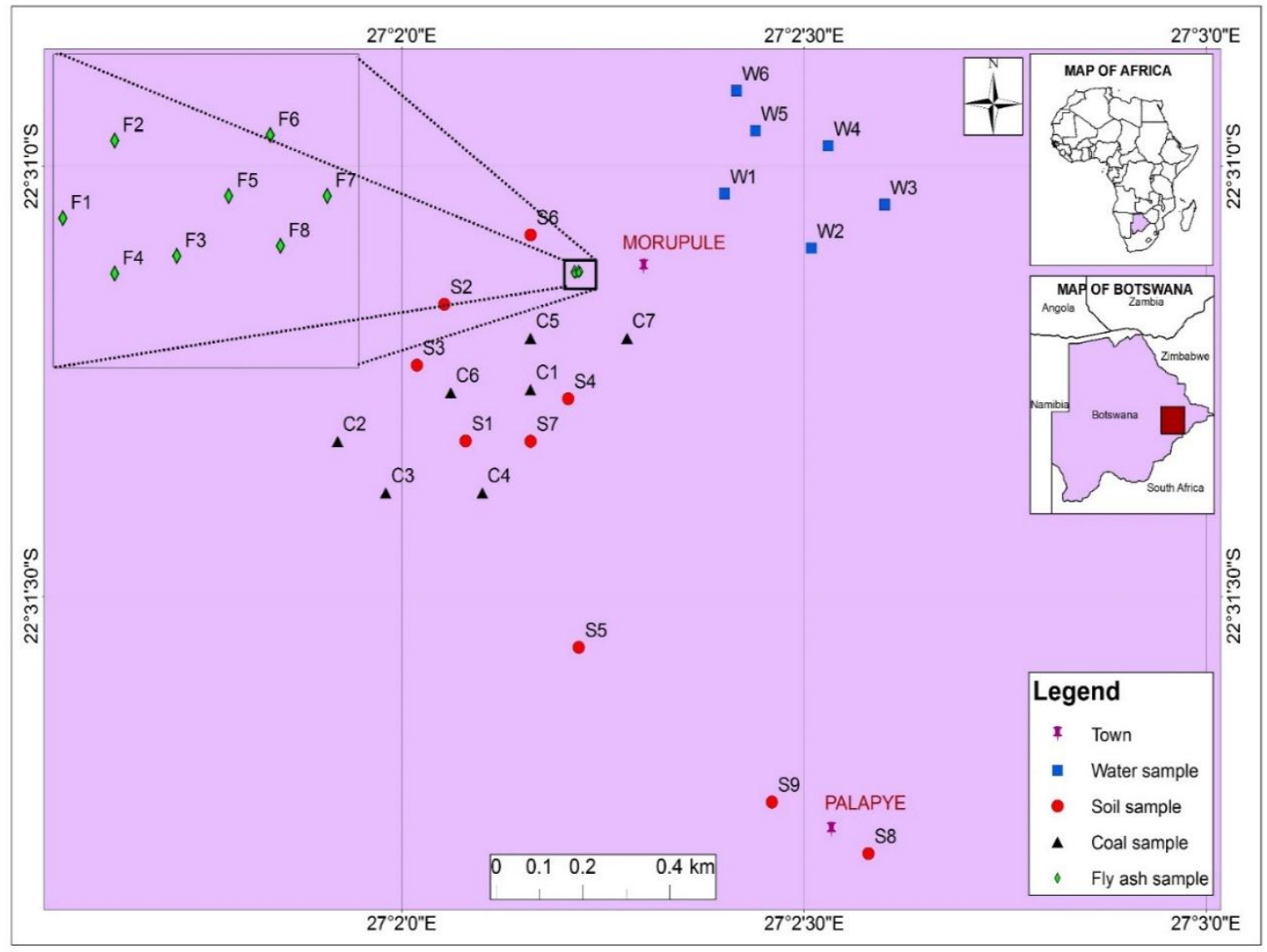

Fig. 1:-Sampling points from the study area

\section{Materials and methods:-}

\section{Sampling and sample preparation}

30 samples of various matrices were collected from the study area. These comprised of 6 water samples from the fly ash ponds, 9 soil samples, 7 bituminous coal samples from the coal storage area and 8 fly ash samples from the fly ash storage area. Soil samples from different areas were collected to a depth of $20 \mathrm{~cm}$ with a coring tool and sealed into pre-labelled polythene bags. Fly ash and bituminous coal samples from different locations were scooped and sealed into pre-labelled polythene bags. Grass, roots and other visible foreign objects were manually removed from the coal and soil samples. Clean and pre-labelled $1 \mathrm{~L}$ polythene containers were used to collect water samples from various areas within the fly ash pond. Visible coarse material were filtered out, after which the water samples were spiked with $1 \mathrm{M} \mathrm{HNO}_{3}$ and then sealed with their respective lids.

At the laboratory all the ash/soil/coal samples were air dried in the laboratory for 10 days, after which they were oven-dried to a constant weight for 3 hours at $105{ }^{\circ} \mathrm{C}$ [Faanu, 2011]. Coal and soil samples were ground into a fine powder before being sieved into pre-weighed 1 liter Marinelli beakers. The dried fly ash powder samples were directly added into pre-weighed 1 liter Marinelli beakers. The collected water samples were filtered into preweighed 1 liter Marinelli beakers. All the 30 Marinelli beakers with samples were then tightly sealed with their respective lids and white tape and stored for 30 days prior to being counted on a High Purity Germanium Detector [Faanu, 2011; Agalga, Darko and Schandorf, 2013; Ademola and Onyema, 2014]. 


\section{Radiological hazard assessment}

Soil and fly ash from the study area may be used as building material. Fly ash is an excellent substitute for concrete, cement and clay [Ademola and Onyema, 2014]. The radium equivalent activity concentration $\left(\mathrm{Ra}_{\mathrm{eq}}\right)$, external hazard $\left(\mathrm{H}_{\mathrm{ext}}\right)$ and internal hazard $\left(\mathrm{H}_{\mathrm{int}}\right)$ indices are used to assess the radiological hazard due to natural radioactivity from the fly ash, coal, soil and water which may be used as construction material. The only natural radionuclides considered in this radiological assessment are ${ }^{40} \mathrm{~K},{ }^{226} \mathrm{Ra}$ and ${ }^{232} \mathrm{Th}$. Calculations of $R a_{\text {eq }}, H_{\text {ext }}$ and $H_{\text {int }}$ were done by means of Equations 1 to 3 respectively:

$$
\begin{aligned}
& \text { 1. } R a_{e q}=A_{\mathrm{Ra}}+1.43 A_{\mathrm{Th}}+0.077 A_{\mathrm{K}} \\
& \text { 2. } H_{\text {ext }}=A_{\mathrm{Ra}} / 370+A_{\mathrm{Th}} / 259+A_{\mathrm{K}} / 4810 \leq 1 \\
& \text { 3. } H_{\text {int }}=A_{\mathrm{Ra}} / 185+A_{\mathrm{Th}} / 259+A_{\mathrm{K}} / 4810 \leq 1
\end{aligned}
$$

Where, $A_{\text {Ra }}, A_{\mathrm{Th}}$ and $A_{\mathrm{K}}$ are activity concentrations for natural radionuclides ${ }^{226} \mathrm{Ra},{ }^{232} \mathrm{Th}$ and ${ }^{40} \mathrm{~K}$ in $\mathrm{Bq} / \mathrm{kg}$ respectively. $\mathrm{Ra}_{\mathrm{eq}}$ index basis is on the estimation that the same gamma dose rate is produced by $1 \mathrm{~Bq} / \mathrm{kg}$ of ${ }^{226} \mathrm{Ra}$, $0.7 \mathrm{~Bq} / \mathrm{kg}$ of ${ }^{232} \mathrm{Th}$ and $13 \mathrm{~Bq} / \mathrm{kg}$ of ${ }^{40} \mathrm{~K}$. In order to ensure that bulding materials are safe to use with respect to radiation, the maximum $R a_{e q}$ for these materials must not exceed $370 \mathrm{~Bq} / \mathrm{kg}$. The maximum allowed values for $H_{e x t}$ and $H_{\text {int }}$ are unity and dimensionless [Ademola and Onyema, 2014]. The representative level index $I_{\gamma r}$ is a radiation index hazard that is used to esimate the level of $\gamma$ radiation hazard [Harb et al., 2008; NEA-OECD, 1979] due to natural radionuclides in samples and is represented by Equation 4 below:

$$
I_{\gamma r}=A_{\mathrm{Ra}} / 150+A_{\mathrm{Th}} / 100+A_{\mathrm{K}} / 1500
$$

Where, $A_{\mathrm{Ra}}, A_{\mathrm{Th}}$ and $A_{\mathrm{K}}$ are activity concentrations for natural radionuclides ${ }^{226} \mathrm{Ra},{ }^{232} \mathrm{Th}$ and ${ }^{40} \mathrm{~K}$ in $\mathrm{Bq} / \mathrm{kg}$ respectively. In order for the radiation hazard to be negligible, the value of the representative level index $I_{\gamma r}$ must be less than unity [Harb et al., 2008].

\section{Results and discussion:-}

\section{Radiation hazard of material from the study area}

Figure 2 outlines and compares the representative level index $\left(\mathrm{I}_{\gamma r}\right)$, radium equivalent activity $\left(\mathrm{Ra}_{e q}\right)$, external hazard index $\left(\mathrm{H}_{\text {ext }}\right)$ and internal hazard index $\left(\mathrm{H}_{\text {int }}\right)$ associated with natural radionuclides in fly ash, coal, soil and water samples respectively. It is important to assess the gamma radiation hazards on humans associated with the use of any of the above samples as building material by calculating the values of $\mathrm{I}_{\gamma r}, \mathrm{Ra}_{e q}, \mathrm{H}_{\text {ext }}$ and $\mathrm{H}_{\text {int }}$ for all samples [Harb et al., 2008]. For example, fly ash is used in making cement or as a lightweight filler for concrete [Penfold et al., 1998]. The radium equivalent activity $\left(\mathrm{Ra}_{e q}\right)$, external hazard index $\left(\mathrm{H}_{\text {ext }}\right)$, internal hazard index $\left(\mathrm{H}_{\text {int }}\right)$ and representative level index $\left(\mathrm{I}_{\gamma r}\right)$ were computed by means of Equations 1, 2, 3 and 4 respectively. As seen in Figure 2, the average $\mathrm{Ra}_{e q}, \mathrm{I}_{\gamma r}, \mathrm{H}_{\text {int }}$ and $\mathrm{H}_{\text {ext }}$ values for fly ash samples were $149.038 \mathrm{~Bq} / \mathrm{kg}, 1.031,0.536$ and 0.403 respectively. In the case of coal samples, the average $\mathrm{Ra}_{e q}, \mathrm{I}_{\gamma r}, \mathrm{H}_{\text {int }}$ and $\mathrm{H}_{\text {ext }}$ values are $58.662 \mathrm{~Bq} / \mathrm{kg}, 0.407$, 0.207 and 0.158 respectively. From Figure 2, the average $\mathrm{Ra}_{e q}, \mathrm{I}_{\gamma r}, \mathrm{H}_{\text {int }}$ and $\mathrm{H}_{\text {ext }}$ values for soil samples are 30.296 $\mathrm{Bq} / \mathrm{kg}, 0.225,0.100$ and 0.082 respectively. Those for water samples are $1.516 \mathrm{~Bq} / \mathrm{kg}, 0.011,0.005$ and 0.004 respectively.

The calculated values for $R a_{e q}, \mathrm{I}_{\gamma r}, \mathrm{H}_{\text {int }}$ and $\mathrm{H}_{e x t}$ in this study are generally highest for fly ash, followed by coal, soil and water samples in descending order. These relatively high fly ash values of $R a_{e q}, \mathrm{I}_{\gamma r}, \mathrm{H}_{\text {int }}$ and $\mathrm{H}_{\text {ext }}$ could be attributed to the fact that when coal is combusted, most of the non-combustible material, which includes the natural radionuclides, remains and concentrates in the fly ash thereby enhancing the $R a_{e q}, \mathrm{I}_{\gamma r}, \mathrm{H}_{\text {int }}$ and $\mathrm{H}_{\text {ext }}$ values [Penfold et al., 1998]. The average $R a_{e q}$ values for all the fly ash, coal, soil and water samples are below the internationally accepted value of $370 \mathrm{~Bq} / \mathrm{kg}$. The average values of $H_{\text {ext }}$ and $H_{\text {int }}$ for all the fly ash, coal, soil and water samples are also below the internationally accepted value of unity [Ademola and Onyema, 2014]. The average values of $\mathrm{I}_{\gamma r}$ for all coal, soil and water samples are also below the the internationally accepted value of unity [Harb et al., 2008]. The average value of $\mathrm{I}_{\gamma r}$ for the fly ash samples is approximately equal to the internationally accepted value of unity. Based on these results, it is therefore safe to use these materials under study for construction purposes. 


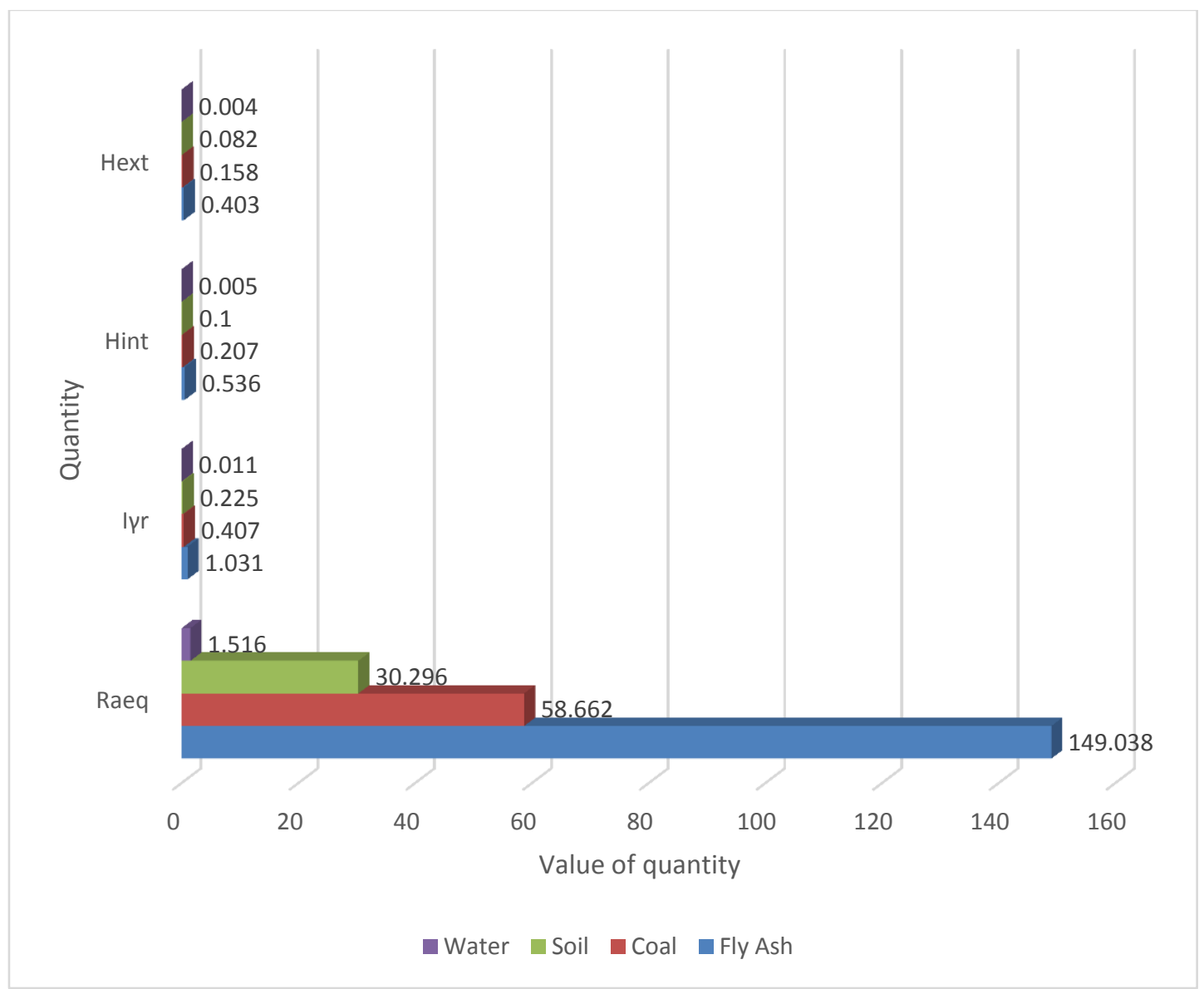

Fig. 2:-Comparison of hazard indices and radium equivalent values for all samples

\section{Conclusions:-}

The aim of this study was to determine the occupational and public radiation hazards due to the usage of fly ash and other environmentals material from Morupule A Coal-Fired Power Station and its environs for construction purposes. The samples analyzed during this study include soil, coal and fly ash within the power station. Areas outside the main power station include soil from the environs of the power station as well as water from the fly ash ponds.

The gamma radiation hazards associated with the use of any of the study samples as building material were assessed by calculating the values of the representative level index $\left(\mathrm{I}_{\gamma r}\right)$, radium equivalent activity $\left(R a_{e q}\right)$, external hazard index $\left(\mathrm{H}_{\text {ext }}\right)$ and internal hazard index $\left(\mathrm{H}_{\text {int }}\right)$. The average $R a_{e q}$ values for all samples were below the internationally accepted value of $370 \mathrm{~Bq} / \mathrm{kg}$. The average values of $\mathrm{H}_{\text {ext }}$ and $\mathrm{H}_{\text {int }}$ for all the samples were also below the internationally accepted value of unity. The average value of $\mathrm{I}_{\gamma r}$ for the fly ash samples was approximately equal to the internationally accepted value of unity, while those of all other samples were way below unity. Based on these results, the materials under study could be used for construction purposes without posing any significant radiological hazards to Morupule A Coal-Fired Power Station workers or to members of the public in the power station or its environs [Faanu, 2011].

\section{Acknowledgements:-}

This research has been completed under an International Atomic Energy Agency (IAEA) scholarship at the University of Ghana, Legon in Accra, Ghana. The sampling was completed with assistance from the personnel of Morupule A Coal-Fired Power Station in Botswana. All gamma spectrometry counting of study samples was done at 
the Radiation Protection Institute of the Ghana Atomic Energy Commission in Accra. All contributions from stakeholders are highly appreciated and acknowledged.

\section{References:-}

1. Ademola, J. A. and Onyema, U. C. (2014). Assessment of Natural Radionuclides in Fly Ash Produced at Orji River Thermal Power Station, Nigeria and the Associated Radiological Impact, Natural Sciences Journal, Vol. 6, pp. 752-759.

2. Agalga R., Darko, E. O. and Schandorf, C. (2013). Preliminary study on the levels of natural radionuclides in sediments of the Tono irrigation dam, Navrongo, International Journal of Science and Technology, Vol. 2, pp. 770-776.

3. Faanu, A. (2011). Assessment of Public Exposure to Naturally Occurring Radioactive Materials from Mining and Mineral Processing Activities of Tarkwa Goldmine in Ghana (PhD Dissertation, February, 2011).

4. Harb, S., El-Kamel, A. H., El-Mageed, A. I. A., Abbady, A. and Rashed, W. (2008). Concentration of U-238, U-235, Ra-226, Th-232 and K-40 for some granite samples in eastern desert of Egypt.

5. NEA-OECD (Nuclear Energy Agency). (1979). Exposure to radiation from natural radioactivity in building materials, OECD, Paris.

6. Penfold, J. S. S., Smith, K. R., Harvey, M. P. and Mobbs, S. F. (1998). Assessment of the radiological impact of coal-fired power stations in the United Kingdom, Didcot, Oxfordshire, pp. 67-71. 